\title{
Uji Kuat Tekan Green Concrete Dari Pemanfaatan Limbah Beton Dan Abu Sekam Padi
}

\author{
Samuel Bryant Agus Jaya1, Didik Ariyanto², \\ Djoko Suwarno ${ }^{3}$, Budi Setiyadi ${ }^{4}$ \\ email: ${ }^{1}$ samuelbrynt.a.j@gmail.com, ${ }^{2} 12$ didikariyanto@gmail.com \\ Program Studi Teknik Sipil, Fakultas Teknik, Unika Soegijapranata, Semarang, Universitas Katolik \\ Soegijapranata; Jl. Pawiyatan Luhur IV/1 Bendan Dhuwur Semarang 50234, 024-8441555
}

\begin{abstract}
Abstrak
Green Concrete adalah beton yang memperhatikan lingkungan. Hal itu, dilakukan melalui inovasi teknologi beton. Pemanfaatan dan penggunaan limbah beton/bahan daur ulang menjadi salah satu solusi terhadap permasalahan lingkungan. Bahan daur ulang diperoleh dengan memanfaatkan limbah beton bangunan yang sudah hancur. Pemanfaatan abu sekam padi untuk mengurangi penggunaan semen dalam campuran beton. Tujuan penelitian ini untuk mengetahui kuat tekan beton dengan mengganti $60 \%$ agregat kerikil alam dengan agregat kasar limbah beton dan mengganti komposisi semen dengan abu sekam padi sebesar 0\% (A60), 8\% (A60:AS8) dan 10\% (A60:AS10). Pengujian sampel silinder beton dilakukan pada umur 7, 14 dan 28 hari dengan total sampel 38 buah. Metode penelitian yang dilakukan meliputi studi literatur, persiapan alat dan material (persiapan material diantaranya penghancuran limbah beton dan pembakaran abu sekam padi), perencanaan mix design, pembuatan sampel beton dan pembahasan. Hasil kuat tekan beton A60 sebesar 23,638 MPa, beton A60:AS8 sebesar 24,638 MPa, beton A60:AS10 sebesar 23,968 MPa. Beton A60:AS8 mengalami peningkatan kuat tekan sebesar 2,9\% dari beton A60. Hasil kuat tekan optimum terdapat pada beton A60:AS8 dengan kuat tekan sebesar 24,345 MPa.
\end{abstract}

Kata kunci : Green Concrete, Limbah beton, Abu sekam padi, Kuat Tekan beton

\begin{abstract}
Green Concrete is concrete that takes into account the environment. That was done through concrete technological innovation. Utilization and use of concrete waste / recycled materials is one solution to environmental problems. Recycled material is obtained by utilizing concrete waste from buildings that have been destroyed. Utilization of natural rice husk ash to reduce the use of cement in concrete mixes. The purpose of this study was to determine the compressive strength of concrete by replacing $60 \%$ of natural gravel aggregate with coarse aggregate of concrete waste and replacing cement composition with rice husk ash by 0\% (A60), 8\% (A60: AS8) and 10\% (A60: AS10). Concrete cylinder sample testing was carried out at 7, 14 and 28 days with a total sample of 38 pieces. The research methods carried out include the study of literature, preparation of tools and materials (material preparation including the destruction of concrete waste and burning of rice husk ash),planning mix design, concrete sample making and discussion. The yield of compressive strength of A60 concrete is 23,638 MPa, A60: AS8 concrete is 24,638 MPa, A60: AS10 concrete is 23,968 MPa. Concrete A60: AS8 experienced a compressive strength increase of $2.9 \%$ over A60 concrete. The optimum compressive strength results are found in concrete A60: AS8 with compressive strength of 24,345 MPa.
\end{abstract}

Keywords: Green Concrete, Concrete,waste, Rice husk ash, Concrete Compressive Strength 


\section{PENDAHULUAN}

\subsection{Latar Belakang}

Indonesia merupakan negara yang memiliki resiko tinggi bagi terjadinya bencana karena secara geologis terletak pada pertemuan lempeng Eurasia, IndoAustralia dan Lempeng Pasifik (Desfandi, 2014). Menurut data dari Badan Nasional Penanggulangan Bencana (BNPB) di tahun 2018 gempa bumi dan banjir merupakan bencana alam yang paling besar menimbulkan dampak bagi masyarakat. Dampak yang ditimbulkan ketika terjadinya bencana alam diantaranya adalah korban jiwa maupun kerusakan fasilitas infrastruktur.

Perkembangan teknologi di bidang konstruksi bangunan harus dilakukan untuk menyelesaikan dan meminimalkan dampak bencana alam. Dampak yang ditimbulkan terhadap bangunan berupa kerusakan hingga timbulnya limbah bangunan. Limbah bangunan yang dihasilkan berupa pecahanpecahan beton, partisi dinding, besi hingga material kayu. Selain bencana alam limbah bangunan banyak dihasilkan dari pekerjaan konstruksi. Data Badan Pusat Statistik tahun 2018 nilai konstruksi yang diselesaikan di seluruh wilayah Indonesia mengalami peningkatan dari Rp 839.205.661 menjadi $\mathrm{Rp}$ 958.015.034. Dengan meningkatnya jumlah infrastruktur maka cadangan sumber daya alam akan berkurang dan berakibat pada meningkatnya limbah sebagai hasil proses konstruksi maupun setelah bangunan tersebut habis masa pakai nya (Ervianto dkk., 2012). Limbah beton merupakan limbah bangunan yang kurang dapat diolah kembali dibandingkan dengan material yang lain. Sebagian besar limbah yang dihasilkan hanya dibuang begitu saja atau digunakan sebagai material urugan. Sangat diperlukan suatu teknologi konstruksi yang dapat mengurangi eksploitasi alam dan dapat memanfaatkan limbah-limbah beton. Salah satu upaya mengurangi dampak tersebut dengan menggunakan kembali limbah beton untuk penggunaan beton baru. Ini menjadi alternatif bahan beton yang menguntungkan, karena agregat yang digunakan adalah agregat yang telah dibuang (Soelarso dkk, 2016). Dengan demikian penggunaan kembali agregat atau waste material dapat mendukung konsep green concrete yaitu mengurangi, menggunakan kembali dan mendaur ulang. Green concrete mendukung tiga pilar keberlanjutan: dampak lingkungan, ekonomi, dan sosial (Suhendro, 2014).

Hasil penelitian terkait penggunaan material beton daur ulang, perbandingan penurunan kuat tekan sebesar 7\% untuk penggunaan agregat kasar dari limbah beton dibandingkan beton normal (Mulyati dan Arman, 2014). Penelitian tersebut menunjukkan penggunaan agregat kasar daur ulang dapat menurunkan nilai kuat tekan beton. Inovasi lain tentang beton daur ulang yaitu terkait penggunaan beton daur ulang dengan bahan tambah abu terbang (fly ash) dan serbuk kaca sebagai subtitusi parsial semen. Hasil penelitian pengujian kuat tekan beton daur ulang dengan fly ash sebagai pengganti sebagian semen menghasilkan nilai kuat tekan optimum pada 20\% fly ash sebesar $18.61 \mathrm{MPa}$, sedangkan variasi dengan kadar $20 \%$ fly ash dan 5\% serbuk kaca sebagai substitusi parsial semen menghasilkan nilai kuat tekan yang optimum sebesar $16.93 \mathrm{MPa}$ (Punusingon dkk, 2019). Penelitian penggunaan beton daur ulang dengan bahan tambah lain perlu dilakukan untuk memperoleh hasil kuat tekan yang lebih optimum, salah satunya penggunaan abu sekam padi. Hasil penelitian penggunaan abu sekam padi dapat meningkatkan kuat tekan beton optimum dengan penambahan ASP sebesar 8\% (Tata dkk, 2016). Penelitian lain presentase optimum 
penggunaan ASP adalah $10 \%$ dari berat semen (Abdian dan Herbudiman, 2010). Oleh karena itu perlu dilakukan penelitian lebih lanjut untuk mengetahui pengaruh substitusi material abu sekam padi terhadap kadar semen yang digunakan. Harapannya dapat menaikkan nilai kuat tekan beton daur ulang tersebut, dikarenakan pada abu sekam padi terdapat senyawa silika yang berfungsi sebagai pengikat.

\subsection{Perumusan Masalah}

Pentingnya membuat terobosan beton daur ulang maupun beton ramah lingkungan merupakan tantangan yang harus dilakukan di masa mendatang. Rumusan masalah penelitian ini adalah sebagai berikut:

1. Seberapa banyak komposisi campuran yang digunakan untuk memperoleh mutu beton daur ulang tinggi dengan bahan pengganti berupa abu sekam padi dan agregat kasar limbah beton.

2. Seberapa besar perbedaan kekuatan beton alami dengan beton daur ulang.

\subsection{Batasan Masalah}

Dalam penelitian ini terdapat batasan-batasan sebagai berikut:

1. Kuat tekan beton fc' 24,9 MPa.

2. Benda uji yang digunakan yaitu: Silinder dengan ukuran $\varnothing 15 \mathrm{~cm}$, tinggi $30 \mathrm{~cm}$ sebanyak 38 buah. Pengujian kuat tekan di umur beton 7 dan 14 hari masing-masing umur dibuat 12 buah silinder. Sedangkan pengujian kuat tekan pada umur beton 28 hari sebanyak 14 buah silinder.

3. Agregat kasar alam dan agregat kasar daur ulang yang digunakan yaitu agregat yang tertahan pada saringan no. $4(4,75 \mathrm{~mm})$.

4. Abu sekam padi yang digunakan yaitu lolos saringan no. $200(0,075 \mathrm{~mm})$.
5. Semen yang digunakan adalah semen Portland tipe I (Ordinary Portland Cement).

6. Bahan pengganti yang digunakan:

Abu sekam padi yang digunakan dengan komposisi 0\%, 8\% dan 10\% dari berat total semen.

Agregat kasar limbah beton yang digunakan sebesar $60 \%$ dari total agregat kasar yang digunakan.

7. Proses penghancuran limbah beton dengan cara manual.

\subsection{Tujuan Penelitian}

Penelitian terkait dengan pengaruh penggunaan abu sekam padi dan agregat kasar limbah beton sebagai pengganti semen maupun agregat bertujuan untuk:

1. Mengetahui uji kuat tekan beton yang bisa dihasilkan dari penggunaan abu sekam padi dan limbah beton.

2. Mengetahui perbandingan nilai kuat tekan antara material beton alami dengan material beton daur ulang.

\section{TINJAUAN PUSTAKA}

\subsection{Pertumbuhan Konstruksi di Indonesia}

Berdasarkan data Badan Pusat Statistik tahun 2010-2017, nilai konstruksi cenderung mengalami peningkatan. Meningkatnya nilai konstruksi yang diselesaikan dapat diartikan bahwa semakin tinggi aktivitas pembangunan proyek konstruksi di Indonesia (BPS, 2019). 


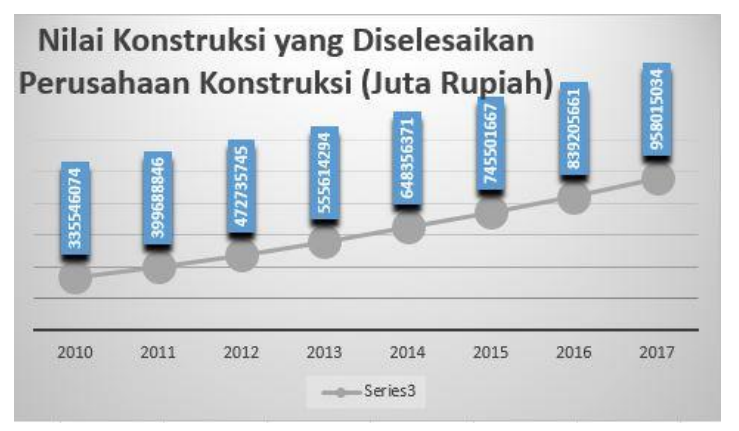

Gambar 2.1.

Nilai Konstruksi yang Diselesaikan (Sumber:https://www.bps.go.id/dynamict able /2015/09/19/929/nilai-konstruksiyang-diselesaikan menurut-provinsi-danbidang-pekerjaan-2007---2016.html)

\subsection{Kerusakan Bangunan akibat Bencana Alam}

Indonesia merupakan negara yang rentan terhadap terjadinya bencana alam seperti gempa bumi, tsunami, letusan gunung berapi, tanah longsor, banjir dan angin puting beliung. Menurut hasil data Badan Nasional Penanggulangan Bencana (BNPB) Tahun 2018 Gempa bumi dan Tsunami adalah bencana yang paling banyak menyebabkan kerusakan bangunan selama 10 tahun terakhir dibandingkan dengan bencana alam lainnya.

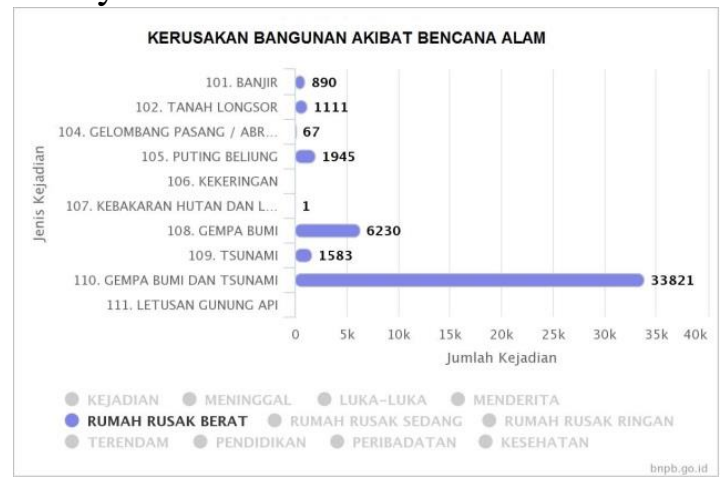

Gambar 2.2.

Kerusakan Bangunan Akibat

Bencana Alam

(Sumber: diunduh dari

https://bnpb.cloud/dibi/grafik1a)

\subsection{Limbah Hasil Proses Konstruksi}

Semakin meningkatnya jumlah infrastruktur maka cadangan sumber daya alam akan berkurang dan berakibat pada meningkatnya limbah sebagai hasil proses konstruksi maupun setelah bangunan tersebut habis masa pakai nya. Lebih jauh lagi dapat diinterpretasikan bahwa semakin tinggi pemanfaatan sumber daya alam maka akan semakin besar beban lingkungan yang diakibatkan oleh limbah konstruksi. Berdasarkan data BPKP (Badan Pengawasan Keuangan dan Pembangunan) melalui Keputusan Gubernur Nomor 1227 Tahun 1989, luas wilayah Provinsi DKI Jakarta adalah $7.659,02 \mathrm{~km} 2$, terdiri dari daratan seluas $661,52 \mathrm{~km} 2$, termasuk 110 pulau di Kepulauan Seribu, dan lautan seluas 6.997,50 km2. Menurut catatan Collier International Research, luas bangunan kantor baru di Jakarta adalah $551.670 \mathrm{~m} 2$, luas total existing bangunan kantor adalah $5.948 .590 \mathrm{~m} 2$ sehingga luas total bangunan kantor adalah $6.500 .260 \mathrm{~m} 2$. Struktur utama bangunan gedung yang umum digunakan adalah beton bertulang dengan perkiraan masa pakai \pm 50 tahun. Jika setiap $1 \mathrm{~m} 2$ bangunan menimbulkan limbah $\pm 0,3542 \mathrm{~m} 3$ material komponen struktur bangunan, maka dalam 50 tahun mendatang limbah struktur bangunan yang akan ditimbulkan sebesar $\pm 2.302 .392 \mathrm{~m} 3$ (Ervianto dkk., 2012). Tentu saja volume yang sangat besar ini akan menjadi beban bagi lingkungan apabila tidak ada rencana sejak awal dan tindakan untuk mengelola secara baik.

\subsection{Pengelolaan Limbah Konstruksi}

Para pelaku industri konstruksi di negara yang lebih maju telah merubah pola pengelolaan proyek dan berusaha melakukan efisiensi agar limbah yang terbentuk sesedikit mungkin. Tidak hanya limbah dari proses konstruksi saja yang 
perlu diperhatikan namun bangunan yang sudah habis masa pakainya berpotensi menimbulkan limbah dalam jumlah yang sangat besar. Beberapa alternatif yang dapat dilakukan untuk mengelola bangunan yang telah habis masa pakainya sejalan dengan konsep $3 \mathrm{R}$ adalah: (a) melakukan konservasi dengan memperkuat struktur bangunan sehingga bangunan aman untuk digunakan kembali, (b) merobohkan bangunan (dekonstruksi) dan mengganti dengan bangunan baru. Dalam hal dekonstruksi bangunan, proses ini tentu akan menghasilkan limbah yang lebih besar. Pokok persoalannya adalah bagaimana mekanisme membuang limbah ke lingkungan agar tidak menimbulkan dampak negatif terhadap lingkungan dan bagaimana cara memanfaatkan limbah hasil dekonstruksi terkait dengan isu menipisnya cadangan sumber daya alam di Bumi.

\subsection{Green Concrete}

Pertumbuhan dan percepatan ekonomi dunia yang semakin tinggi sekarang ini menjadikan bangunan berbahan beton berkembang di banyak tempat. Oleh karena itu kebutuhan untuk produksi beton mengalami peningkatan jumlah secara signifikan. Dampaknya negatif produksi beton seringkali menyebabkan timbulnya kerusakan lingkungan; dari proses menambang batu kapur, proses pembakaran, hingga menimbulkan emisi, dsb. Produksi semen dalam pembahasan di forum beton hijau berkelanjutan dinyatakan sebagai penyumbang karbondioksida terbesar nomor dua dunia, setelah pembangkit listrik. Dengan kadar karbondioksida yang dihasilakan sebanyak tujuh persen. Karenanya perlu senantiasa dikembangkan beton ramah lingkungan sehingga pembangunan tidak perlu berhenti demi lingkungan.
Beton yang menggunakan lebih sedikit energi dalam produksinya dan menghasilkan lebih sedikit $\mathrm{CO}_{2}$ daripada beton normal disebut beton hijau (Beton ramah lingkungan). Pembuatan material penyusun beton yang ramah lingkungan ini dapat dilakukan dengan mewujudkan 3 (tiga) usaha kelangsungan dan konservasi lingkungan, yaitu:

a. Pengurangan emisi gas rumah kaca (terbesar adalah $\mathrm{CO}_{2}$ )

b. Efisiensi energi dan material dasar

c. Penggunaan material buangan/waste

d. Pengurangan efek yang mengganggu kesehatan/keselamatan pada pengguna konstruksi, baik yang timbul selama proses konstruksi ataupun yang timbul selama operasi bangunan, dengan menggunakan Konsep 4R (Reduce, Refurbish, Reuse and Recycle).

\subsubsection{Sejarah Beton Hijau}

Beton Hijau adalah topik revolusioner dalam sejarah industri beton. Konsep ini pertama kali dikemukakan di Denmark pada tahun 1998, konsep beton hijau lebih dari sekedar pewarnaan. Ini adalah konsep berpikir lingkungan ke dalam beton yang mempertimbangkan setiap aspek dari bahan baku hingga cara memproduksi lebih dari desain campuran untuk desain struktural, konstruksi, dan umur. Beton hijau sangat murah untuk diproduksi, karena produk limbah yang digunakan sebagai pengganti sebagian semen, biaya untuk pembuangan limbah dihindari, konsumsi energi dalam produksi lebih rendah, dan daya tahan yang lebih besar. Beton Hijau merupakan jenis beton seperti beton konvensional akan tetapi produksi atau pembuatan beton tersebut membutuhkan energi yang minim dan tidak menyebabkan kerusakan lingkungan. Emisi gas rumah kaca dihasilkan dari berbagai aktivitas industri. Sumber- 
sumber emisi utama adalah dilepaskannya (gas rumah kaca) dari proses-proses industri yang secara kimiawi atau fisik melakukan transformasi suatu bahan/material menjadi bahan lain (misal blast furnace di industri besi dan baja, produksi amonia dan produk-produk kimia lainnya dari bahan baku berupa bahan bakar fosil,serta proses produksi semen). Proses-proses tersebut dapat menghasilkan berbagai gas rumah kaca diantaranya karbon dioksida (CO2), metana $(\mathrm{CH} 4)$, nitrous oksida $(\mathrm{N} 2 \mathrm{O})$, hidrofluorokarbon (HFC) dan perfluorokarbon (PFC). Selain itu, gas rumah kaca juga digunakan sebagai bahan baku di dalam produk-produk seperti pada refrigerator, busa atau kaleng aerosol. Sebagai contoh, HFC yang digunakan sebagai alternatif bahan pengganti bahan perusak ozon (BPO) dalam berbagai jenis aplikasi produk. Demikian pula, sulfur heksafluorida (SF6) dan N2O yang digunakan dalam sejumlah produk yang digunakan dalam industri. Emisi gas $\mathrm{CO} 2$ yang dihasilkan saat produksi beton, termasuk proses produksi semen, adalah antara 0,1 sampai $0,2 \mathrm{t}$ per ton beton yang diproduksi. Akan tetapi, karena jumlah produksi beton yang dihasilkan besar sehingga berdampak signifikan terhadap lingkungan.

\subsection{Konsep 3 R (Reduce, Reuse, Recycle) dalam Dunia Konstruksi}

Konsep 3R (Reduce, Reuse, Recycle) telah diperkenalkan dalam industri manufaktur dan berpotensi diimplementasikan dalam industri konstruksi. Penerapan konsep reduce secara langsung terjadi dalam tahap konstruksi, meskipun secara tidak langsung tahap perencanaan berkontribusi terhadap banyak sedikitnya limbah yang dihasilkan. Konsep reuse dalam implementasinya terjadi setelah masa pakai/operasional bangunan habis. Pemanfaatannya dapat melalui dekonstruksi yang dilanjutkan dengan daur ulang.

\subsection{Dekonstruksi Bangunan}

Dekonstruksi

adalah pembongkaran bangunan yang bertujuan untuk mendapatkan material atau komponen bangunan yang masih dapat digunakan kembali dan untuk mendapatkan material baru melalui proses daur ulang. Salah satu strategi dalam membongkar sebuah bangunan adalah memilih material yang masih mempunyai nilai dan membuang yang benar-benar tidak dapat digunakan lagi. Dekonstruksi juga dapat didefinisikan sebagai pembongkaran bangunan secara hati-hati yang bertujuan untuk memaksimalkan penggunaan kembali komponen bangunan dan meminimalkan jumlah bahan yang dibuang ke lingkungan/alam (Ervianto dkk., 2012). Salah satu manfaat nyata dekonstruksi adalah mendapatkan komponen bangunan yang masih dapat digunakan dan mereduksi jumlah limbah yang dibuang ke lingkungan/alam sehingga terbentuk siklus tertutup dalam penggunaan material. Pada umumnya pekerjaan dekonstruksi dilakukan secara manual oleh tukang atau menggunakan peralatan berat yang dilakukan secara hatihati. Jika dibandingkan dengan demolisi, dekonstruksi membutuhkan waktu yang lebih lama dikarenakan tujuan proses ini adalah melepas komponen bangunan untuk digunakan kembali dalam pembangunan lainnya (Ervianto dkk, 2012). Menurut Ervianto dkk (2012) Pertimbangan yang digunakan dalam memilih dekonstruksi atau demolisi didasarkan pada:

a. Kualitas dan jumlah material yang masih berpotensi untuk digunakan

b. Pertimbangan pasar terhadap 
material/komponen yang masih dapat digunakan

c. Adanya material yang berbahaya

d. Waktu yang tersedia untuk membongkar bangunan.

\subsection{Beton Daur Ulang}

Beton daur ulang merupakan salah satu agregat buatan (artificial aggregates). Material ini berasal dari bangunan yang telah habis masa pakai nya sehingga terpaksa dibongkar karena bangunan tersebut perlu diperbaharui, mengalami kerusakan, atau tidak layak lagi dihuni. Beton Daur Ulang merupakan campuran yang diperoleh dari proses ulang material yang sebelumnya. Beberapa perbedaan kualitas, sifat-sifat fisik dan kimia agregat daur ulang, menyebabkan perbedaan sifatsifat material beton yang dihasilkan, seperti menurunnya kuat tekan, kuat tarik, dan modulus elastisitas nya (Punusingon $\mathrm{dkk}, 2019)$. Ada Beberapa poin yang harus dimengerti dalam pemanfaatan agregat beton bekas adalah kebutuhan air dalam proses pengadukan yang lebih tinggi dikarenakan sifat penyerapan air yang besar, disisi lain waktu untuk proses pemadatan menjadi lebih lama karena nilai plastisitas nya rendah dan juga permukaan agregat menjadi lebih kasar.

\subsection{Pengertian Beton}

Menurut SK SNI T-15-1990-03, beton merupakan campuran antara semen Portland, agregat kasar, dan air, dengan atau tanpa bahan campuran tambahan membentuk massa padat (Susilorini dan Suwarno, 2009).

Ada tiga alasan penyebab material beton sering digunakan pada dunia konstruksi. Alasan pertama yaitu beton merupakan bahan yang kedap air. Alasan kedua yaitu elemen struktur beton mudah dicetak menjadi berbagai ukuran dan tipe. Alasan ketiga beton merupakan material yang mudah disediakan dan relatif lebih murah.

\subsection{Beton Normal}

Beton normal menurut SNI 032847-2002 adalah beton yang mempunyai berat isi $2200-2500 \mathrm{~kg} / \mathrm{m} 3$ dengan agregat alam yang dipecah maupun tanpa dipecah. Beton yang banyak dijumpai dan dipakai saat ini adalah beton normal. Ditinjau dari nilai kuat tekannya, beton normal mempunyai nilai kuat tekan yang berkisar antara 20-40 MPa.

Sesuai dengan peningkatan kekuatan beton maka kinerja dari beton itu sendiri juga akan meningkat. Kinerja tersebut diantaranya adalah durabilitas, modulus elastisitas, permeabilitas, rangkak, serta daya tahan terhadap panas dan korosi.

\subsection{Agregat}

Agregat berfungsi sebagai bahan pengisi beton. Karakteristik agregat yang penting dan berhubungan dengan teknologi beton adalah porositas, distribusi gradasi dan ukuran, serapan kelembaban, bentuk dan tekstur permukaan, kekuatan pecah, modulus elastisitas dan adanya zat-zat merusak beton. Klasifikasi agregat tergantung dari ukuran butir, kerapatan, dan asal agregat. Menurut ukuran butirnya, agregat digolongkan menjadi agregat kasar, yang mempunyai partikel lebih besar dari 4,75 $\mathrm{mm}$, dan agregat halus, dengan partikel lebih kecil dari pada 4,75 mm (Susilorini dan Suwarno, 2009).

\subsection{Klasifikasi Beton}

Klasifikasi beton berdasarkan kekuatannya dibedakan menjadi 3 kategori. Kategori pertama yaitu beton mutu rendah dengan kuat tekan kurang dari $20 \mathrm{MPa}$. Beton mutu sedang dengan kuat tekan antara 20 sampai dengan 40 $\mathrm{MPa}$. Kategori terakhir yaitu beton mutu 
tinggi dengan kuat tekan diatas $40 \mathrm{MPa}$ (Susilorini dan Suwarno, 2009).

\subsection{Pemanfaatan Abu Sekam Padi sebagai Substitusi Penggunaan Semen Pada Green Concrete}

Abu sekam padi (risk husk ash) merupakan limbah yang dihasilkan dari pengolahan padi. Abu sekam padi bersifat pozzolanic yang berarti kandungan material terbesar nya adalah silika dan baik digunakan pada campuran pozzolan kapur yang berfungsi sebagai pengikat kapur bebas yang timbul pada saat semen mengalami hidrasi.

Tabel 2.1 Komposisi Kimia Abu Sekam

Padi Lolos Saringan No. 200

\begin{tabular}{|c|c|}
\hline Komposisi & Persentase (\%) \\
\hline Silicon dionxide $\left(\mathrm{SiO}_{2}\right)$ & 85,73 \\
\hline Alumunium oxide $\left(\mathrm{Al}_{2} \mathrm{O}_{3}\right)$ & 2,29 \\
\hline Ferric oxide $\left(\mathrm{Fe}_{2} \mathrm{O}_{3}\right)$ & 0,82 \\
\hline Calcium oxide $(\mathrm{CaO})$ & 1,12 \\
\hline Magnesium oxide $(\mathrm{MgO})$ & 0,40 \\
\hline Hilang pijar & 7,18 \\
\hline
\end{tabular}

Sumber: Hidayat, 2011

\subsection{Keuntungan dan Keterbatasan Beton}

Keuntungan dari penggunaan material beton yaitu kuat, tahan lama (awet), kedap air, dan mempunyai sifat susut yang relatif kecil. Kelemahan dari penggunaan beton yaitu beton tidak tahan terhadap gaya tarik sehingga diberi tulangan baja di dalamnya untuk menahan gaya tarik (Susilorini dan Suwarno, 2009).

\subsection{Pengujian Beton Segar}

Karakteristik beton segar perlu untuk dipelajari karena berpengaruh terhadap pemilihan peralatan yang digunakan dalam pelaksanaan, pemadatan maupun sifat beton dalam kondisi mengeras.

\subsection{Uji Silinder SNI 1974-2011}

Hasil dari pengujian sangat dipengaruhi oleh prosedur pelaksanaan. Benda uji yang mempunyai kekuatan tekan normal berdasarkan uji SNI 1974-
2011 menggunakan silinder dengan perbandingan panjang dan garis tengah ( 1 : $\mathrm{d}=2: 1$ ) alat yang dibutuhkan dalam uji silinder SNI 1974-2011:

1. Silinder, biasanya digunakan $\mathrm{d}=150$ mm dan panjang $(\mathrm{l})=300 \mathrm{~mm}$

2. Cetakan terbuat dari logam berbentuk lempengan atau dari papan.

\subsection{Kuat Tekan Beton}

Kuat tekan beton adalah besarnya beban per satuan luas, yang menyebabkan benda uji hancur bila dibebani dengan gaya tekan tertentu, yang dihasilkan oleh mesin pembebanan (Wariyatno dan Haryanto, 2013). Kuat tekan beton merupakan salah satu sifat yang penting dari beton dibandingkan dengan sifat yang lainnya. Kekuatan tekan beton ditentukan dari perencanaan campuran beton yang dapat ditentukan dari perbandingan semen, agregat, air dan bahan tambah yang digunakan.

Nilai kuat tekan beton didapatkan dengan cara pengujian standar dengan menggunakan mesin uji. Benda uji beton yang digunakan merupakan silinder dengan dimensi $15 \mathrm{~cm} \times 30 \mathrm{~cm}$. Silinder beton kemudian diberi beban bertingkat dengan kecepatan peningkatan tertentu dengan mesin kuat tekan sampai beton tersebut hancur. Untuk mendapatkan besarnya tegangan hancur pada benda uji silinder digunakan rumus:

$\mathrm{fc}^{\prime}=\mathrm{P} / \mathrm{A}$

Keterangan:

$\mathrm{fc}^{\prime}$ = Kuat tekan beton benda uji silinder (MPa)

$\mathrm{P}=$ Beban desak maksimum $(\mathrm{N})$

$\mathrm{A}=$ Luas permukaan benda uji silinder (mm2)

\section{METODE PENELITIAN}

Dalam penelitian ini ada tiga tahapan proses yang dilakukan. Berikut 
adalah diagram alir untuk menjelaskan tahapan penelitian yang diperlihatkan pada Gambar 3.1.

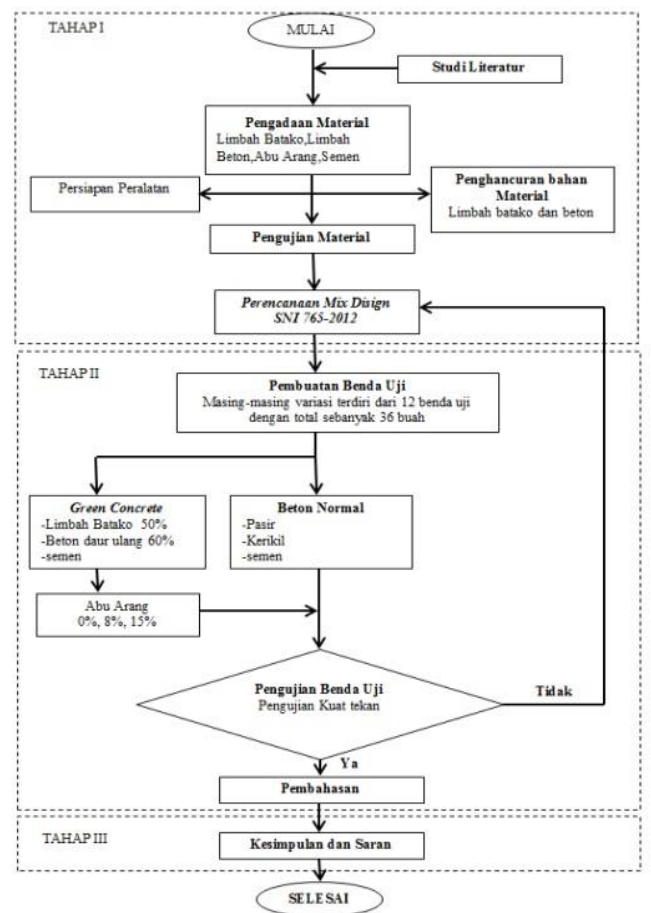

Gambar 3.1 Diagram Alir Penelitian

\subsection{Tahap I}

Pada tahap I, adalah tahap persiapan yang terdiri dari mengumpulkan studi literatur maupun dasar-dasar teori yang dibutuhkan dalam proses pelaksanaan penelitian. Pada tahap ini juga dilakukan persiapan alat dan bahan yang nantinya digunakan. Setelah mempersiapkan alat dan bahan dilanjutkan dengan pemeriksaan seluruh agregat.

1. Studi Literatur

Literatur yang digunakan dalam penelitian ini didapat dari berbagai macam sumber seperti jurnal yang terdapat di internet, buku yang terdapat di perpustakaan, serta dari tugas akhir dan disertasi dari penelitian terdahulu.

2. Persiapan Bahan

Material yang digunakan adalah agregat halus alam, agregat kasar alam, agregat kasar limbah beton, semen, abu sekam padi dan air yang berasal dari Laboratorium Beton Unika Soegijapranata.

\section{Persiapan Alat}

Peralatan yang digunakan dalam penelitian ini yaitu cetakan silinder diameter $15 \mathrm{~cm}$ dan tinggi $30 \mathrm{~cm}$, alat slump test, Oven, Mesin Pengguncang Saringan, dan lain-lain.

4. Penghancuran Bahan Material

Bahan material yang telah dikumpulkan berupa limbah beton yang sudah tidak terpakai kemudian dihancurkan secara manual dengan peralatan palu beton hingga mencapai ukuran agregat yang sesuai.

5. Pengujian Material

a. Pengujian analisis saringan agregat halus

Pengujian analisis saringan yang mengacu pada SNI 03-1968-1990,

b. Pengujian kandungan lumpur dan kandungan organis pada agregat halus. Pada pengujian ini yang mengacu pada SNI 2816:2014,

6. Perencanaan Mix Design

Setelah pengujian material dilakukan dan memenuhi persyaratan, tahap selanjutnya yaitu perencanaan mix design. Penelitian ini menggunakan perencanaan mix design metode SNI 7656:2012.

Tabel 3.1 Tabel Uji Coba Campuran

Untuk Menghasilkan Sifat-sifat Beton

Dengan Menggunakan

\section{Bahan-bahan Lokal}

\begin{tabular}{|c|c|c|c|c|c|c|c|c|c|c|c|}
\hline \multicolumn{9}{|c|}{ Berat $(\mathbf{k g}) /$ /volume $\left(\mathbf{m}^{3}\right)$} & \multicolumn{5}{|c|}{ Sifat-sifat beton } \\
\hline $\begin{array}{c}\text { No } \\
\text { Camp }\end{array}$ & $\mathbf{1}$ & $\mathbf{2}$ & $\mathbf{3}$ & \multicolumn{2}{|c|}{ Air } & Jumlah & $\mathbf{4}$ & $\mathbf{5}$ & $\mathbf{6}$ & $\mathbf{7}$ & $\mathbf{8}$ \\
\hline & & & Per & Pem & & & & & & \\
\hline 1 & 297 & 816 & 1074 & 193 & 208 & 2394 & 101,6 & 2354,94 & 0,78 & - & $\begin{array}{c}\text { Pasir } \\
\text { berlebih }\end{array}$ \\
\hline 2 & 297 & 742 & 1112 & 205 & 202 & 2352 & 76,2 & 2354,94 & 0,76 & 23,10 & $0 . k$. \\
\hline 3 & 237 & 792 & 1112 & 205 & 205 & 2347 & 114,3 & 2330,91 & 0,77 & 14,69 & $0 . k$. \\
\hline 4 & 267 & 765 & 1112 & 205 & 205 & 2349 & 101,6 & 2342,12 & 0,77 & 18,00 & $0 . k$. \\
\hline 5 & 326 & 718 & 1112 & 205 & 205 & 2361 & 76,2 & 2362,95 & 0,76 & 26,20 & $0 . k$. \\
\hline 6 & 356 & 691 & 1112 & 205 & 205 & 2364 & 88,9 & 2375,77 & 0,76 & 30,06 & $0 . k$. \\
\hline
\end{tabular}


Keterangan:

1: Semen

2: Pasir

3: Agregat Kasar

4: Slump mm

5: Berat satuan $\mathrm{kg} / \mathrm{m}^{3}$

6:Yield $\mathrm{m}^{3}$

7: Kuat tekan $28 \mathrm{hr} \mathrm{MPa}$

8:Kemudahan Pengerjaan (Per=perkiraan, Pem=pemakaian)

sumber: Tata cara pemilihan campuran

untuk beton normal, beton berat dan beton Massa SNI 7656:2012.

\subsection{Tahap II}

Pada tahap II, adalah tahap pembuatan benda uji dilanjutkan dengan proses perawatan benda uji dan pengujian terhadap benda uji tersebut.

1. Pembuatan Benda uji

Pembuatan benda uji pada penelitian ini yaitu silinder dengan diameter $15 \mathrm{~cm}$ dan tinggi $30 \mathrm{~cm}$. Berikut merupakan langkah-langkah pembuatan benda uji dengan concrete mixer.

a. Agregat kasar alam, agregat kasar limbah beton, agregat halus alam, semen dan abu sekam padi yang sudah ditimbang sesuai dengan perencanaan diaduk secara manual sampai tercampur dengan baik.

b. Memasukkan air sesuai dengan perencanaan ke dalam adukan beton.

c. Tahap selanjutnya yaitu melakukan slump test.

d. Apabila nilai slump test sudah sesuai dengan perencanaan kemudian adukan beton tersebut dimasukkan ke dalam benda uji silinder.

e. Benda uji yang masih berada di dalam cetakan kemudian diletakkan di tempat yang tidak terkena matahari.

f. Membuka cetakan setelah $1 \times 24$ jam dari waktu pembuatan benda uji. Benda uji dalam penelitian ini berjumlah 38 buah silinder dengan diameter $15 \mathrm{~cm}$ dan tinggi $30 \mathrm{~cm} .12$ benda uji untuk pengujian umur 7 hari, 12 benda uji berikutnya untuk pengujian umur 14 hari, dan 14 benda uji untuk pengujian pada umur 28 hari.

2. Perawatan (Curing)

Perawatan benda uji dilakukan setelah cetakan dibuka. Benda uji diberi tanda atau tulisan agar mudah dibedakan. Proses perawatan benda uji dalam penelitian ini dengan cara direndam dalam bak perendaman hingga benda uji berumur 7 hari, 14 hari, dan 28 hari.

3. Pengujian Benda Uji

a. Pengujian Kuat Tekan

Pengujian benda uji yang dilakukan pada penelitian ini yaitu pengujian kuat tekan beton. Pengujian dilakukan saat beton berumur 7 hari, 14 hari, dan 28 hari. Uji kuat tekan beton pada penelitian ini menggunakan alat concrete compression machine. Uji kuat tekan beton dilakukan di Laboratorium Bahan Bangunan Unika Soegijapranata.

4. Pembahasan

Pada tahap III, adalah tahap penyusunan kesimpulan maupun saran yang diperoleh setelah melakukan penelitian. Dalam tahap ini hasil pengujian dan analisis data yang diperoleh dijadikan dasar untuk menunjang tujuan dari penelitian yang sudah dilakukan maupun penelitian berikutnya.Pembahasan dilakukan dengan cara membandingkan nilai kuat tekan yang didapat dari pengujian dengan kuat tekan rencana.

\subsection{Tahap III}

Pada tahap III, adalah tahap penyusunan kesimpulan maupun saran yang diperoleh setelah melakukan penelitian. Dalam tahap ini hasil pengujian dan analisis data yang diperoleh dijadikan 
dasar untuk menunjang tujuan dari penelitian yang sudah dilakukan maupun penelitian berikutnya.

\section{HASIL DAN PEMBAHASAN} 4.1. Hasil Uji Kuat Tekan Beton

Dari hasil uji kuat tekan beton menggunakan Concrete Compression Machine, didapatkan hasil sebagai berikut:

\subsubsection{Hasil Uji Kuat Tekan Usia 7 Hari}

Pada saat beton berusia 7 hari dilakukan pengetesan agar dapat diketahui hasil dari kuat tekan beton dalam 4 varian. Berikut ini adalah hasil perhitungan hasil pengujian kuat tekan beton saat berusia 7 hari:

1.Perhitungan luas penampang benda uji (A)

$$
\begin{aligned}
\mathrm{A} & =1 / 4 \times \pi \times \mathrm{D}^{2} \\
& =1 / 4 \times 3,1416 \times 1502 \\
& =17671,5 \mathrm{~mm}^{2}
\end{aligned}
$$

\section{Keterangan:}

$\mathrm{A}=$ luas penampang benda uji $\left(\mathrm{mm}^{2}\right)$

$\pi=$ konstanta $(3,1416)$

$\mathrm{D}=$ diameter benda uji silinder $(\mathrm{mm})$

Perhitungan kuat tekan benda uji silinder Kuat tekan $(\mathrm{MPa})$

$$
\begin{aligned}
& =((\text { Gaya Tekan maksimum } \times 1000)) / \mathrm{A} \\
& =((355 \times 1000)) / 17671,5 \\
& =20,099 \mathrm{Mpa}
\end{aligned}
$$

\begin{tabular}{|c|c|c|c|c|c|c|c|c|}
\hline $\begin{array}{l}\text { Kode Benda } \\
\text { Uji }\end{array}$ & $\begin{array}{l}\text { Umur } \\
\text { (hari) }\end{array}$ & $\begin{array}{c}\text { Berat } \\
\text { Benda Uji } \\
(\mathbf{k g})\end{array}$ & $\begin{array}{l}\text { Dimen } \\
\text { si } \\
\text { Silind } \\
\text { er } \\
(\mathrm{cm})\end{array}$ & $\begin{array}{l}\text { Luas } \\
\left(\mathrm{mm}^{2}\right)\end{array}$ & $\begin{array}{c}\text { Gaya } \\
\text { Teka } \\
\text { n } \\
(\mathbf{k N})\end{array}$ & $\begin{array}{c}\text { Gaya } \\
\text { Tekan } \\
(\mathrm{N})\end{array}$ & $\begin{array}{c}\text { Kuat } \\
\text { Tekan } \\
\text { Silinder } \\
\left(\mathrm{N} / \mathrm{mm}^{2}\right) \\
= \\
\mathrm{MPa}\end{array}$ & $\begin{array}{c}\text { Kuat } \\
\text { Tekan } \\
\text { Rata-rata } \\
\left(\mathrm{N} / \mathrm{mm}^{2}\right) \\
= \\
\mathrm{MPa}\end{array}$ \\
\hline \multirow{3}{*}{ N } & 7 & 12,44 & $15 \times 30$ & 17671,5 & 355 & 355000 & 20,099 & \multirow[t]{3}{*}{$\frac{18,5}{18,59}$} \\
\hline & 7 & 12,43 & $15 \times 30$ & 17671,5 & 310 & 310000 & 17,551 & \\
\hline & 7 & 12,20 & $15 \times 30$ & 17671,5 & 320 & 320000 & 18,117 & \\
\hline \multirow{3}{*}{ A60 } & 7 & $\begin{array}{ll}11,93 \\
11,93\end{array}$ & $15 \times 30$ & 17671,5 & 280 & 280000 & 15,853 & \multirow[t]{3}{*}{16,513} \\
\hline & 7 & 12,28 & $15 \times 30$ & 17671,5 & 300 & 300000 & 16,985 & \\
\hline & 7 & 12,07 & $15 \times 30$ & 17671,5 & 295 & 295000 & 16,702 & \\
\hline \multirow{3}{*}{ A60:AS8 } & 7 & 12,54 & $15 \times 30$ & 17671,5 & 330 & 330000 & 18,684 & \multirow[t]{3}{*}{17,363} \\
\hline & 7 & 12,31 & $15 \times 30$ & 17671,5 & 320 & 320000 & 18,117 & \\
\hline & 7 & 12,29 & $15 \times 30$ & 17671,5 & 270 & 270000 & 15,287 & \\
\hline \multirow{3}{*}{$\mathrm{A} 60: \mathrm{AS} 10$} & 7 & 12,31 & $15 \times 30$ & 17671,5 & 290 & 290000 & 16,419 & \multirow[t]{3}{*}{16,796} \\
\hline & 7 & 12,27 & $15 \times 30$ & 17671,5 & 290 & 290000 & 16,419 & \\
\hline & 7 & 12,37 & $15 \times 30$ & 17671,5 & 310 & 310000 & 17,551 & \\
\hline
\end{tabular}

Berdasarkan perhitungan hasil kuat tekan beton pada usia 7 hari, maka didapat data seperti pada Tabel 4.1
Tabel 4.1 Hasil Kuat Tekan Beton Umur 7 Hari

Keterangan kode:

$\mathrm{N}=$ Beton normal

A60 =Agregat kasar beton daur ulang $60 \%$ dari total berat agregat kasar.

A60:AS8 = Perbandingan Agregat kasar beton daur ulang $60 \%$ ditambah Abu Sekam padi $8 \%$ dari berat semen.

A60:AS10 = Perbandingan Agregat kasar beton daur ulang $60 \%$ ditambahAbu Sekam padi $10 \%$ dari berat semen.

Berdasarkan Tabel 4.1 dapat diketahui bahwa kuat tekan tertinggi saat beton berusia 7 hari terdapat pada beton normal yaitu sebesar $18,589 \mathrm{MPa}$ dan kemudian mengalami penurunan pada variasi penggunaan agregat kasar beton daur ulang sebesar $60 \%$ dengan kuat tekan sebesar 16,513 MPa. Gambar 4.1 adalah grafik uji kuat tekan usia 7 hari.

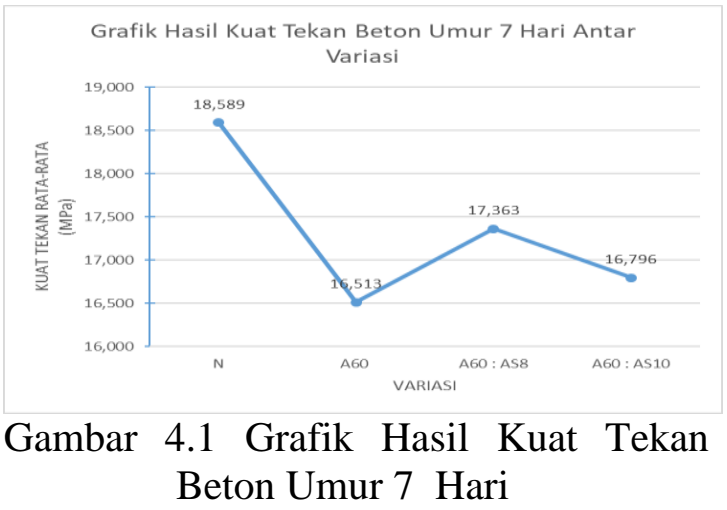




\subsubsection{Hasil Uji Kuat Tekan Usia 14 Hari}

Pada saat beton berusia 14 hari dilakukan pengetesan agar dapat diketahui hasil dari kuat tekan beton dalam 4 varian. Berdasarkan perhitungan hasil kuat tekan beton pada usia 14 hari, maka didapat data seperti pada Tabel 4.2

Tabel 4.2 Hasil Kuat Tekan Beton Umur 14 Hari

\begin{tabular}{|c|c|c|c|c|c|c|c|c|}
\hline $\begin{array}{l}\text { Kode } \\
\text { Benda Uji }\end{array}$ & $\begin{array}{l}\text { Umur } \\
\text { (hari) }\end{array}$ & $\begin{array}{c}\text { Berat } \\
\text { Benda } \\
\text { Uji (kg) }\end{array}$ & $\begin{array}{c}\text { Dimensi } \\
\text { Silinder } \\
(\mathrm{cm})\end{array}$ & $\begin{array}{l}\text { Luas } \\
\left(\mathrm{mm}^{2}\right)\end{array}$ & $\begin{array}{l}\text { Gaya } \\
\text { Tekan } \\
(k N)\end{array}$ & $\begin{array}{c}\text { Gaya } \\
\text { Tekan } \\
(\mathrm{N})\end{array}$ & $\begin{array}{c}\text { Kuat } \\
\text { Tekan } \\
\text { Silinder } \\
\left(\mathrm{N} / \mathrm{mm}^{2}\right) \\
= \\
\mathrm{MPa}\end{array}$ & $\begin{array}{c}\text { Kuat } \\
\text { Tekan } \\
\text { Rata-rata } \\
\left(\mathrm{N} / \mathbf{m m}^{2}\right) \\
= \\
\mathrm{MPa}\end{array}$ \\
\hline \multirow{3}{*}{$\mathrm{N}$} & 14 & 12,42 & $15 \times 30$ & 17671,5 & 380 & 380000 & 21,515 & \multirow[t]{3}{*}{23,213} \\
\hline & 14 & 12,08 & $15 \times 30$ & 17671,5 & 470 & 470000 & 26,610 & \\
\hline & 14 & 11,94 & $15 \times 30$ & 17671,5 & 380 & 380000 & 21,515 & \\
\hline \multirow{3}{*}{ A60 } & 14 & 12,36 & $15 \times 30$ & 17671,5 & 400 & 400000 & 22,647 & \multirow[t]{3}{*}{17,363} \\
\hline & 14 & 12,42 & $15 \times 30$ & 17671,5 & 230 & 230000 & 13,022 & \\
\hline & 14 & 12,09 & $15 \times 30$ & 17671,5 & 290 & 290000 & 16,419 & \\
\hline \multirow{3}{*}{ A60:AS8 } & 14 & 12,38 & $15 \times 30$ & 17671,5 & 360 & 360000 & 20,382 & \multirow[t]{3}{*}{21,515} \\
\hline & 14 & 12,54 & $15 \times 30$ & 17671,5 & 340 & 340000 & 19,250 & \\
\hline & 14 & 12,56 & $15 \times 30$ & 17671,5 & 440 & 440000 & 24,912 & \\
\hline \multirow{3}{*}{ A60:AS10 } & 14 & 12,35 & $15 \times 30$ & 17671,5 & 370 & 370000 & 20,948 & \multirow[t]{3}{*}{20,571} \\
\hline & 14 & 12,34 & $15 \times 30$ & 17671,5 & 350 & 350000 & 19,816 & \\
\hline & 14 & 12,35 & $15 \times 30$ & 17671,5 & 370 & 370000 & 20,948 & \\
\hline
\end{tabular}

Berdasarkan Tabel 4.2 dapat diketahui bahwa kuat tekan tertinggi saat beton berusia 14 hari terdapat pada beton normal yaitu sebesar 23,213 $\mathrm{MPa}$ dan kemudian mengalami penurunan pada variasi penggunaan agregat kasar beton daur ulang sebesar $60 \%$ dengan kuat tekan sebesar 17,363 MPa. Gambar 4.2 adalah grafik uji kuat tekan usia 14 hari.

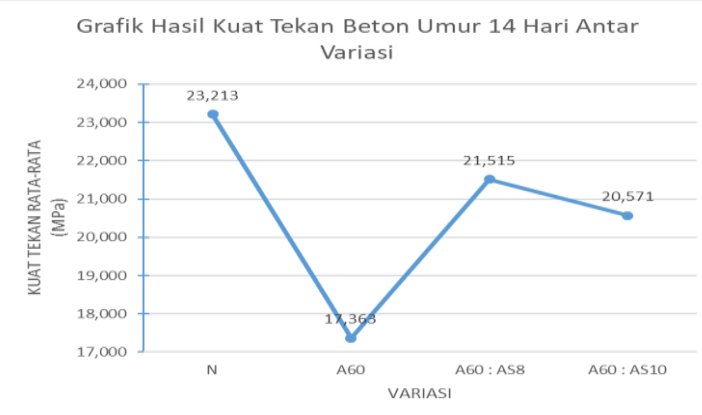

Gambar 4.2 Grafik Hasil Kuat Tekan

Beton Umur 14 Hari

\subsubsection{Hasil Uji Kuat Tekan Usia 28 Hari}

Pada saat beton berusia 28 hari dilakukan pengetesan agar dapat diketahui hasil dari kuat tekan beton dalam 4 varian. Berdasarkan perhitungan hasil kuat tekan beton pada usia 28 hari, maka didapat data seperti pada Tabel 4.3

Tabel 4.3 Hasil Kuat Tekan Beton Umur 28 Hari

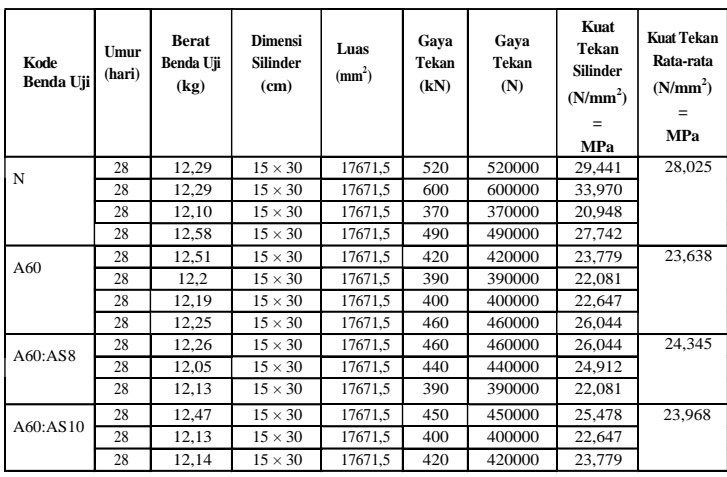

Berdasarkan Tabel 4.3 dapat diketahui bahwa kuat tekan beton normal pada umur 28 hari yaitu sebesar 28,025 $\mathrm{MPa}$ dan kemudian mengalami penurunan pada variasi penggunaan agregat kasar beton daur ulang sebesar $60 \%$ dengan kuat tekan sebesar 23,638 MPa. Gambar 4.3 adalah grafik uji kuat tekan usia 28 hari.

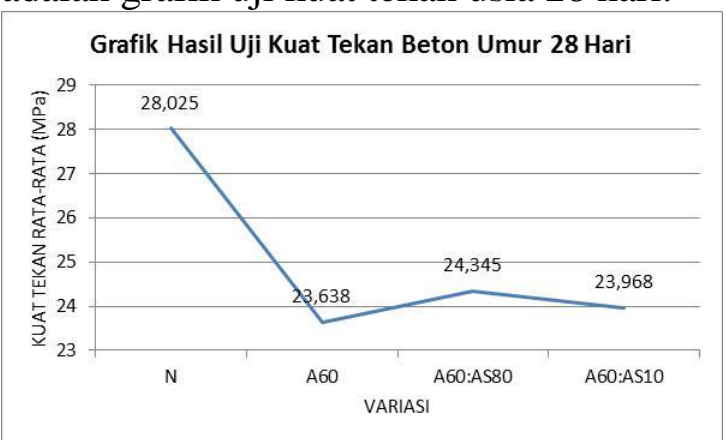

Gambar 4.3 Grafik Hasil Kuat Tekan Beton Umur 28 Hari

\subsection{Pembahasan Hasil Uji Kuat Tekan Beton}

Hasil pendataan yang diperoleh dari keseluruhan pengujian beton saat umur 7 hari 14 hari dan 28 hari dapat digambarkan dengan grafik yang ditampilkan dalam Gambar 4.4. Gambar 4.4 menunjukkan perbandingan antara hasil kuat tekan dengan umur pengujian yang dilakukan dari setiap variasi beton uji yang dibuat. 


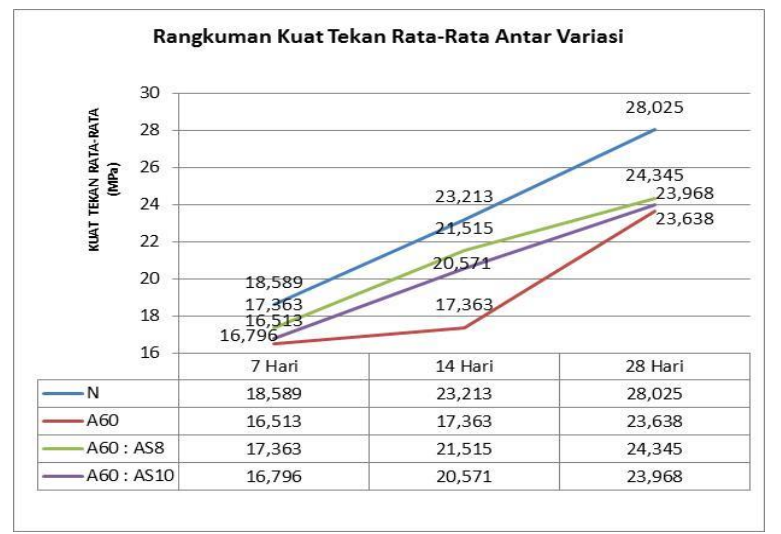

Gambar 4.4 Rangkuman Kuat Rata-Rata Antar Variasi

Dari hasil percobaan uji kuat tekan beton dapat dilihat perbandingan grafik antar variasi beton. Garis merah, hijau maupun ungu merupakan variasi beton dengan komposisi penggunaan $60 \%$ agregat kasar dari limbah beton dan $8 \%$ penggunaan abu sekam padi untuk grafik hijau dan penggunaan $10 \%$ abu sekam padi untuk grafik ungu. Hasil pengujian dua variasi beton dengan penggunaan abu sekam padi mengalami pola kenaikan yang stabil dibandingkan variasi beton lainnya dan mencapai kuat tekan di umur 28 hari rata-rata lebih tinggi dibandingkan beton beton A60. Hasil ini sesuai dengan penelitian yang dilakukan oleh Tata dkk (2016) maupun Abdian dan Herbudiman (2010) Berdasarkan hasil penelitian ini penggantian abu sekam padi yang paling optimum adalah $8 \%$ dari berat semen.

\section{PENUTUP}

\subsection{Kesimpulan}

Kesimpulan yang dapat diambil setelah melakukan penelitian kajian kuat tekan beton dengan pemanfaatan limbah beton sebagai subtitusi $60 \%$ dari total berat agregat kasar dan pemanfaatan abu sekam padi sebagai substitusi $8 \%$ dan $10 \%$ dari total berat semen yaitu:
1. Kuat tekan rata-rata pada 4 variasi beton pada percobaan pertama di umur 7 hari yaitu: beton $\mathrm{N}=18,589$ $\mathrm{MPa}$, beton $\mathrm{A} 60=16,513 \mathrm{MPa}$, beton A60:AS8=17,363 MPa, dan beton A60:AS10=16,796 MPa lalu pada umur 14 hari adalah beton $\mathrm{N}=23,213$ $\mathrm{MPa}$, beton $\mathrm{A} 60=17,363 \mathrm{MPa}$, beton A60:AS8=21,515 $\mathrm{MPa}$, dan beton A60:AS10=20,571 MPa kemudian pada umur 28 hari adalah beton $\mathrm{N}=28,025 \mathrm{MPa}$, beton $\mathrm{A} 60=23,638$ $\mathrm{MPa}$, beton A60:AS8=24,345 MPa, dan beton A60:AS10=23,968 MPa.

2. Kuat tekan rencana yaitu fc' 24,9 Mpa tercapai dengan didapatkan hasil rata-rata kuat tekan beton terbesar adalah 28,025 MPa yang merupakan sampel beton normal umur 28 hari.

3. Perbandingan kuat tekan beton normal dan beton A60 mengalami penurunan sesuai dengan hasil penelitian yang pernah dilakukan oleh Mulyati dan Arman (2014). Hasil penelitian Mulyati dan Arman (2014) menunjukkan penurunan sebesar $7,076 \%$. Sedangkan hasil pengujian dalam penelitian ini yaitu beton $\mathrm{N}=28,025 \mathrm{MPa}$ sedangkan beton $\mathrm{A} 60=23,638 \mathrm{MPa}$ atau sebesar $15,654 \%$.

4. Penggunaan abu sekam padi dapat meningkatkan kuat tekan beton yang dapat dilihat dari kuat tekan pada umur 28 hari. A60:AS8=24,345 $\mathrm{MPa}$ A60:AS10=23,968 $\mathrm{MPa}$ dibandingkan beton $\mathrm{A} 60=23,638 \mathrm{MPa}$ atau terjadi peningkatan sebesar 2,904\%. Sesuai hasil penelitian yang pernah dilakukan oleh Tata dkk (2016) maupun Abdian dan Herbudiman (2010) peningkatan kuat tekan beton sebesar 12,281\%. Dengan hasil penelitian ini peningkatan kuat tekan optimum pada penggantian 
semen menggunakan abu sekam padi sebesar $8 \%$.

\subsection{Kesimpulan}

Dari kesimpulan yang didapat, penulis memberikan saran yaitu antara lain pemilihan agregat kasar harus diperhatikan dengan benar agar agregat kasar yang digunakan memenuhi syarat. Pada penelitian ini penulis juga menyadari masih perlunya beberapa perbaikan untuk mendapatkan hasil yang lebih baik. Adapun saran penelitian selanjutnya yaitu:

1. Kualitas beton dengan pemanfaatan limbah beton dan abu sekam padi dapat mendekati kualitas beton acuan yaitu fc' 24,9 Mpa jika dalam pengolahannya dilakukan secara benar dan efisien.

2. Agregat kasar daur ulang yang digunakan sebaiknya berukuran 1-2 $\mathrm{cm}$ dikarenakan semakin kecilnya ukuran agregat kasar maka beton semakin padat sehingga kuat tekan semakin tinggi dibandingkan dengan hasil kuat dengan penggunaan agregat daur ulang berukuran $2-3 \mathrm{~cm}$.

3. Penggunaan abu sekam padi optimum $8 \%$ harus dilakukan penelitian lanjutan dengan penambahan jumlah sampel uji yang dibuat.

4. Proses pengolahan limbah beton secara manual sebaiknya diganti dengan proses yang lebih efisien (penggunaan mesin penghancur).

\section{DAFTAR PUSTAKA}

Abdian, R. M. dan Herbudiman, B., (2010): Pengaruh kehalusan dan kadar abu sekam padi pada kekuatan beton dengan kuat tekan 50 mpa. KoNTekS 4.Bali: 2-3 Juni 2010. Hal. 2-3.
BPS, (2019): Nilai Konstruksi yang Diselesaikan Perusahaan Konstruksi di Indonesia. Diakses dari:https://www.bps.go.id/dynamicta ble/2015/09/19/929/nilai-konstruksiyang-diselesaikan-menurut-provinsidan-bidang-pekerjaan-2007--2016.html. Diunduh pada tanggal 15 Juli 2019, pukul 20.00 WIB.

BNPB, (2019): Data Kejadian Bencana di Indonesia Tahun 2018. BNPB. diakses dari: https://bnpb.cloud/dibi/laporan5.

Diunduh pada tanggal 13 Agustus 2019, pukul 20.00 WIB.

BNPB, (2019): Kerusakan Bangunan Akibat Bencana Alam. BNPB. Diakses dari: https://bnpb.cloud/dibi/grafik1a.

Diunduh pada tanggal 12 Agustus 2019, pukul 19.30 WIB.

BPKP, (2019): Profil Daerah Khusus Ibukota Jakarta. Diakses dari: http://www.bpkp.go.id/dki1/konten/7 52/Profil-Ibukota.bpkp. Diunduh pada tanggal 10 Agustus 2019, pukul 20.00 WIB.

Desfandi, M., (2014): Urgensi Kurikulum Pendidikan Kebencanaan Berbasis Kearifan Lokal di Indonesia. sosio didaktita 1. pp. 192-197.

Ervianto, W. I. Dkk., (2012): Pengelolaan Bangunan Habis Pakai Dalam Aspek Sustainability. KoNTekS 6. pp. 1-7.

Hidayat, A., (2011): Pengaruh Penambahan Abu Sekam Padi Terhadap Kuat Tekan Beton K-225. Jurnal Aptek. Vol 3 No 2 Juli 2011. 
Mulyati dan Arman, A., (2014): Jurnal Momentum ISSN : 1693-752X Pengaruh Penggunaan Limbah Beton. Jurnal Momentum ISSN : 1693$752 X^{\prime}, 16(2)$.

Punusingon, M, A., Handono, B. D. dan Pendaleke, R., (2019): Uji eksperimental kuat tekan beton daur ulang dengan bahan tambah abu terbang (fly ash) dan serbuk kaca sebagai substitusi parsial semen. Jurnal Sipil Statik. Vol.7 No.1 Januari 2019 (57-66) ISSN: 2337-6732.

Soelarso, Baehaki dan Sidik, N. F., (2016): Pengganti Agregat Kasar pada Beton Normal. Jurnal Fondasi. vol 5(2), pp. 22-29.

Suhendro, B., (2014): Toward Green Concrete for Better Sustainable Environment. Procedia Engineering. Elsevier B.V., 95(Scescm), pp. 305320. doi: 10.1016/j.proeng.2014.12.190.

Susilorini, R dan Djoko S., 2009: Mengenal dan Memahami Teknologi Beton. Laboratorium Bahan Banguna Program Studi Teknik Sipil Universitas Katolik Soegijapranata: Semarang.

SK SNI T-15-1990-03, (1990): Tata Cara Perhitungan Struktur Beton Untuk Bangunan Gedung, Bandung.

SNI 03-1968-1990, (1990): Metode Pengujian Tentang Analisis Saringan Agregat Halus dan Kasar. Badan Standarisasi Nasional, Bandung.
SNI 1974-2011, (2011): Cara Uji Kuat Tekan Beton Dengan Benda Uji Silinder, Bandung.

SNI 7656:2012, (2012): Tata Cara Pemilihan Campuran Untuk Beton Normal,Beton Berat dan Beton Massa, Badan Standarisasi Nasional, Jakarta.

Tata, A., Sultan, M. A. dan Sumartini., (2016): Pengaruh penambahan abu sekam padi sebagai campuran bahan baku beton terhadap sifat mekanis beton. Jurnal Sipilsains. Vol. 06 No. 11 Maret 2016 ISSN : 2088-2076.

Wariyatno, N, G dan Haryanto, Y., (2013): Kuat tekan dan kuat tarik belah sebagai nilai estimasi kekuatan sisa pada beton serat kasa aluminium akibat variasi suhu. Jurnal Dinamika Rekayasa. Vol. 9 No. 1 Februari 2013 ISSN 1858-3075. 